Research, part of a Special Feature on Ecological Restoration in Northern Regions

\title{
Demonstration Restoration Measures in Tributaries of the Vindel River Catchment
}

\author{
$\underline{J o h a n n a ~ G a r d e s t r o ̈ m}^{1}$, Daniel Holmqvist ${ }^{2}$, Lina E. Polvi $^{1}$ and Christer Nilsson $^{1}$
}

\begin{abstract}
Some ecological restoration projects include elements of trial and error where new measures are repeatedly tried, evaluated, and modified until satisfactory results are achieved. Thereafter, the resulting methods may be applied on larger scales. A difficult step is judging whether developed "best-practice" methods have become reasonably ecologically functional or whether further experimentation "demonstration" methods can lead to yet better results. Here, we use a stream restoration project as a case study for evaluating methods and abiotic effects and outlining stakeholder support for demonstration restoration measures, rather than only using best-practice methods. Our work was located in the Vindel River system, a free-flowing river that is part of the Natura 2000 network. The river was exploited for timber floating from 1850-1976, and rapids in the main channel and tributaries below timberline were channelized to increase timber transport capacity. Several side channels in multi-channeled rapids were blocked and the flow was concentrated to a single channel from which boulders and large wood were removed. Hence, previously heterogeneous environments were replaced by more homogeneous systems with limited habitat for riverine species. The restoration project strives to alleviate the effects of fragmentation and channelization in affected rapids by returning coarse sediment from channel margins to the main channel. However, only smaller, angular sediment is available given blasting of large boulders, and large (old-growth) wood is largely absent; therefore, original levels of large boulders and large wood in channels cannot be achieved with standard restoration practices. In 10 demonstration sites, we compensated for this by adding large boulders and large wood (i.e., entire trees) from adjacent upland areas to previously best-practice restored reaches and compared their hydraulic characteristics with 10 other best-practice sites. The demonstration sites exhibited significantly reduced and more variable current velocities, and wider channels, but with less variation than pre-restoration. The ecological response to this restoration has not yet been studied, but potential outcomes are discussed.
\end{abstract}

Key Words: boulders; large wood; northern Sweden; restoration; river; stream; timber floating

\section{INTRODUCTION}

Flowing, freshwater systems have been degraded globally by direct and indirect human influences (Maddock 1999, Malmqvist and Rundle 2002, Nilsson et al. 2005b). Growing awareness of the value of healthy ecosystems and the need to adapt to future changes in climate has put a focus on restoration of ecosystems, especially rivers (Bernhardt et al. 2005, Nilsson et al. 2007, Palmer et al. 2008, Arthington et al. 2010). Recent river restoration approaches include renaturalization of flows; that is, environmental flows (Tharme 2003) and flood protection (Nardini and Pavan 2012); reconfiguration of channels (Nilsson et al. 2005a); defragmentation, that is, dam removal (Bednarek 2001, Lejon et al. 2009), and rebuilding of populations (Luhta et al. 2012). There is a dearth of detailed, scientifically based guidelines for stream restoration. Therefore, some ecological restoration projects apply a trial and error approach to developing methods, whereas others rely on simple guiding principles or myths (cf. Hilderbrand et al. 2005). However, even when restoration methods are developed by testing and evaluating innovative components, it is difficult to know when the most appropriate methods have been achieved. Unfortunately, the potential for learning from, and then improving on, restoration efforts is poorly utilized, because few projects are monitored to demonstrate the longer term results of restoration, and even fewer projects will report on failures (Bernhardt et al. 2005, Jähnig et al. 2011, Kondolf et al. 2011).

Early stream restoration projects were often driven by a single issue and were site based; however, recent policy shifts have moved the focus to more holistic and large-scale restoration efforts (Brookes 2011). Several European Union (EU) Directives are leading to a demand for river restoration projects. For instance, the EU Water Framework Directive (Directive 2000/60/EC), which directs EU member states to achieve good qualitative and quantitative status of all water bodies, prioritizes protection and improvement of the aquatic environment. In addition, the opportunity to receive funding from the EU through its LIFE+ program is a strong driver of restoration efforts. LIFE+ is the EU's financial instrument supporting environmental and nature conservation projects throughout the EU. This program also requires inclusion of monitoring actions in the project plan.

The Vindel River LIFE project is a LIFE+ project focused on restoring tributaries of a river system that was channelized for timber floating. We use this project as a case study for evaluating methods and abiotic effects, and outlining and reporting experiences of stakeholder support for demonstration 
restoration measures, rather than only using best-practice methods. Here, channelization entailed the removal of large boulders, bedrock, and large wood from the channel. These had been placed along the channel edge, effectively disconnecting the channel from the floodplain and blocking any side channels. At a minimum, a best practice in the restoration of timber-floated streams places available coarse sediment from the channel edges back into the channel. Because black powder and dynamite are used to remove boulders and bedrock, such sediment is usually too small to mimic pretimber floating conditions. Therefore, the project responded to scientific recommendations from the literature (Palm et al. 2007, Rosenfeld et al. 2011) and included an experimental component, that is, a demonstration action in which very large boulders and large wood were brought from adjacent uplands and placed into the channel. A central question is whether these additional restoration measures will affect flow conditions in such a way that favors riverine biota. However, it may be difficult to answer this question until biota has had a chance to respond, a process which can take many years. Therefore, the objective of this study was to test whether the demonstration actions have had an effect on channel hydraulics that was significantly different from that of the bestpractice actions.

\section{STUDY AREA}

The Vindel River system is a protected Swedish river and one of the few free-flowing large rivers in Europe (Dynesius and Nilsson 1994). The river is $450 \mathrm{~km}$ long; it originates in the Scandes mountains on the border between Sweden and Norway in the alpine region and joins the heavily regulated Ume River in the boreal region about $40 \mathrm{~km}$ upstream of the Gulf of Bothnia (Fig. 1). During an average year, flows are highest in May-June because of snow melt, and lowest in August-September. In the main channel of the Vindel River, extreme spring floods are more than 100 times larger (1323 $\mathrm{m}^{3} / \mathrm{s}$ ) than extreme winter low flows $\left(9 \mathrm{~m}^{3} / \mathrm{s}\right)$, and 10 times that of average flows (Swedish Meteorological and Hydrological Institute 1979). The discharge is lower in tributaries but the seasonal variation and differences between low and high flows are similar. Spring flooding is short and intense, and discharge fluctuates in response to rain (Nilsson et al. 1994). The Vindel River and its tributaries are part of the Natura 2000 network, which is an EU-wide network of nature protection areas established to ensure the long-term survival of Europe's most valuable and threatened species and habitats. The Vindel River is also one of four major rivers declared as national rivers in Sweden, meaning that they are protected from hydropower development and water diversion to other rivers. The Vindel River suffers from previous exploitation for timber floating, and stands to be improved through restoration efforts.
Fig. 1. The Vindel river catchment in northern Sweden, including the tributaries that have been restored. Notes: The locations of the tributary streams, Olsbäcken and Vormbäcken, which are depcited in the photographs in Fig. 3 and 4, are highlighted. The Baksjöbäcken stream, photographed in Fig. 5, is located in the south-central part of the county.

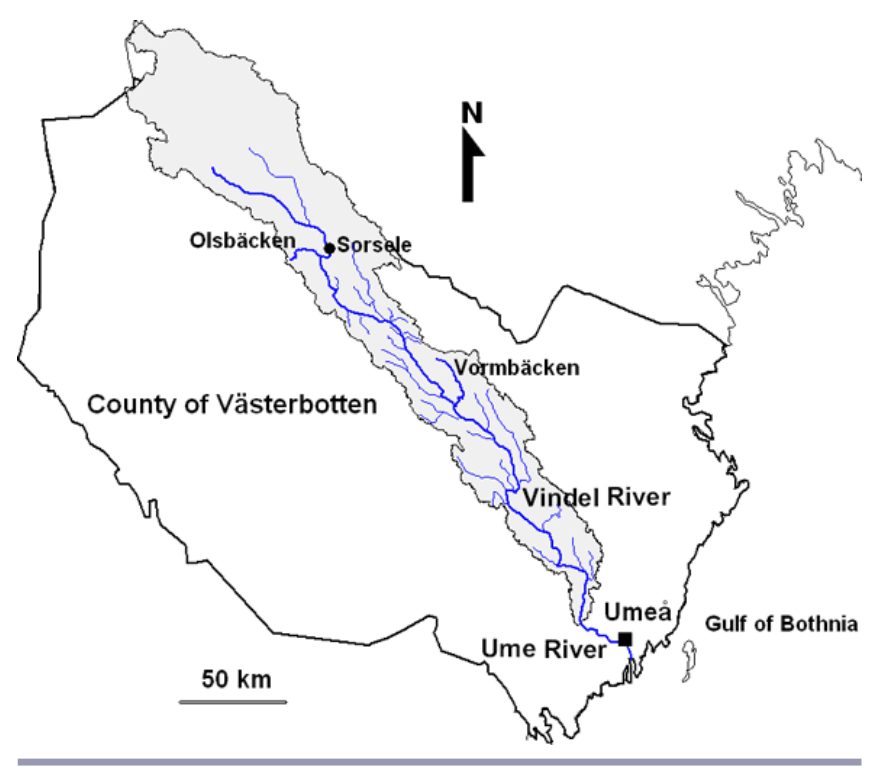

Timber floating has profoundly changed the environmental conditions of many river systems, especially in northern and central Sweden. During the early $1900 \mathrm{~s}$, more than $30,000 \mathrm{~km}$ of river length was channelized in Sweden to facilitate the floating of timber (Törnlund and Östlund 2000, Nilsson et al. $2005 a$ ). On the main stem of the Vindel River and at least 27 of its tributaries, large-scale timber floating started in the $1850 \mathrm{~s}$. The net result of this activity was over $1,600 \mathrm{~km}$ of floated channels and more than 150 splash dams (Törnlund and Östlund 2002). During this time, high-gradient reaches with rapids on the Vindel River and its tributaries were successively channelized (Fig. 2). This was mainly done to increase conveyance and velocities and to shorten the channel. The abiotic effects of channelization include structural homogenization, reduced channel width, increased current velocity and, thus, loss of fine-grained sediment (from rapids). The biotic effects include habitat loss; obstruction of landwater interactions; deterioration or elimination of spawning areas, especially for brown trout (Salmo trutta L.) and European grayling (Thymallus thymallus L.); reduced shelter for fish; and less nutrients and food because of habitat simplification and reduced retention capacity.

Timber transport along streams was gradually replaced by ground transport using trucks starting in the 1950s, and timber 
floating in the Vindel River system ended in 1976. During the final years of floating, the main channel was primarily used; tributaries were phased out first. Attempts to restore parts of the Vindel River exploited by timber floating activities began in the 1990s, when knowledge of river restoration from such activities was still in its infancy. Restoration efforts increased between 2002 and 2005 when a collaborative project encompassing both the Pite River (a similar sized river north of the Vindel River) and Vindel River catchments spurred several restoration activities in the Vindel River and its tributaries (Nilsson 2007). Hence, many of the tributaries have been restored to some extent. In the Vindel River LIFE project, channelized rapids along an additional $44 \mathrm{~km}$ of stream reaches in 22 tributaries are being restored. The project is part of a larger attempt to facilitate fish migration to and from the Vindel River system and also to recover and increase spawning and feeding areas for fish in the catchment.

Fig. 2. Channelized (unrestored) reach of the Vormbäcken stream; the excavator is about to start restoration work. (Photograph: Daniel Jonsson)

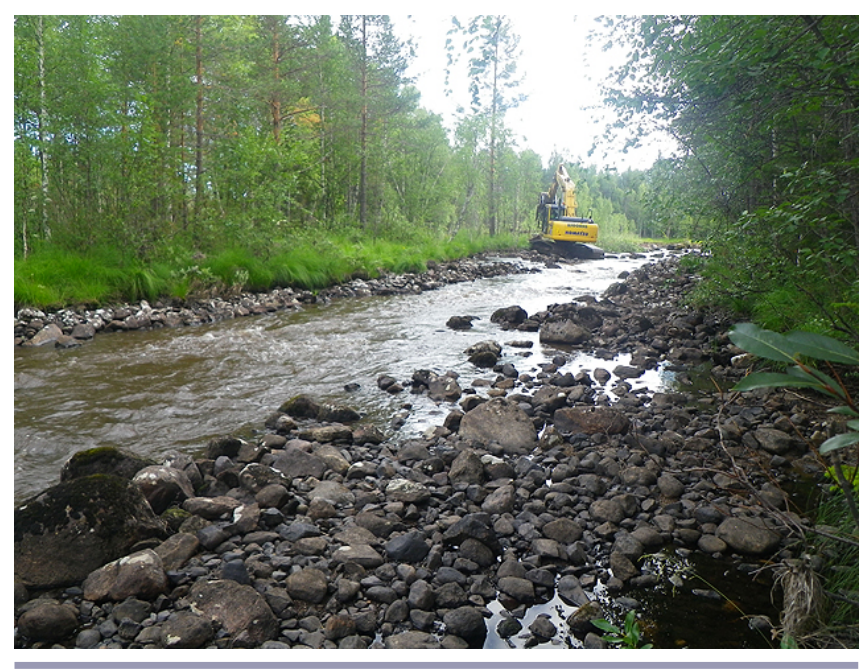

\section{MATERIAL AND METHODS}

\section{Legal work}

Implementation of the restoration work required documentation of affected areas as well as permits and licenses from landowners and public authorities. An initial field inventory laid the foundation for further planning and contacts with landowners and other stakeholders. To date, we have focused on documenting the sites that are owned by large forest companies, as the subsequent legal procedures are less complicated with a single landowner as compared with multiple landowners. Other priorities were to find sites with large boulders on the floodplain or hill slopes near channelized rapids, located reasonably close to roads to provide access for heavy machinery. The legal work preceding restoration actions in the Vindel River tributaries is handled in accordance with the Swedish Environmental Code (Chapter 12, §6), which obliges managers to report activities that may substantially influence the natural environment. Before a site can be restored, local consultation is required, which is achieved through meetings arranged in nearby areas, to which all stakeholders, including landowners, local inhabitants, local fishing-management organizations, Sami villages, etc., are invited. Meeting minutes were written and signed by the meeting organizer, in this case the Vindel River Fishery Advisory Board, and all participants. The landowners have to sign agreements for the restoration action planned on their land. After these are signed, a formal application for permits can be sent to the County Administrative Board of Västerbotten, which is the body issuing authorization to perform restoration work in Natura 2000 sites in this region of Sweden. The legal procedure for all sites in this study was fairly straightforward and was finished before the 2010 field season. The 10 demonstration sites assessed in this study all received restoration permits.

\section{Restoration methods}

All 20 sites assessed in this study underwent best-practice restoration 5-10 years ago, where available coarse sediment from the channel edges was placed in the channel, closed side channels were reopened, and spawning areas for fish were restored wherever possible. In 2010, 10 of these sites became the subject of demonstration restoration, where large boulders and large wood from upland areas were placed in the channels to compensate for the previous losses, following the recommendations of Helfield et al. (2007). The tree species placed in the channel were Scots pine (Pinus sylvestris L.) and Norway spruce (Picea abies (L) H. Karst.) and, less frequently, downy birch (Betula pubescens L.). Trees were placed either diagonally or perpendicular to the flow direction, at a spacing of about one tree per $10 \mathrm{~m}$ of stream length. Most trees were placed with their root wads in the riparian zone, and were left unanchored to allow for restructuring and downstream movement following high flows (Helfield et al. 2007). In deciding the number and location of large boulders to be added to the channel, the availability of boulders in the surrounding floodplain and hill slope was considered, along with the availability of locations to anchor them in the substrate where they would redirect the flow. Restoration of demonstration sites was carried out through August-October 2010 to allow biota to adapt to the new conditions before final monitoring at the end of the project period (in 2014).

Both best-practice and demonstration work is initially done by excavators. A foreman informs the driver where to extract the large boulders and trees, so that the surrounding environment is disturbed as little as possible, and where to place them to achieve desired results. The machine foreman is also responsible for documentation before, during, and after 
Table 1. Mean and standard deviation (SE) for measured parameters in the streams per site and study period, in low and medium water-flow conditions combined.

\begin{tabular}{|c|c|c|c|c|}
\hline Variable & Site & $\begin{array}{l}\text { Study } \\
\text { period }\end{array}$ & Mean & SD \\
\hline \multirow[t]{4}{*}{ Current velocity $(\mathrm{m} / \mathrm{s})$} & reference & before & 0.37 & 0.33 \\
\hline & & after & 0.34 & 0.33 \\
\hline & demonstration & before & $\underline{0.46}$ & 0.37 \\
\hline & & after & $\overline{0.35}$ & 0.33 \\
\hline \multirow[t]{4}{*}{ Stream width $(\mathrm{m})$} & reference & before & $\overline{12.99}$ & 8.50 \\
\hline & & after & 13.83 & 9.70 \\
\hline & demonstration & before & 12.79 & 5.63 \\
\hline & & after & $\underline{14.51}$ & 5.65 \\
\hline
\end{tabular}

Notes: "Before" = prerestoration; "after" = postrestoration of demonstration reaches. Underlined numbers are significantly different $(\mathrm{P}<0.05, t$-test $)$.

the restoration work. In addition, the foreman inventories the streams to decide on placement of new spawning grounds. Thus, the machine foreman needs considerable experience and knowledge about stream hydraulics and ecology, especially regarding fish. The structure of the channel substrate, the surrounding environment, and the channel slope control how the work will be performed and the time it takes. Spawning areas are restored after the excavator work is finished. The primary strategy has been reconstruction of erosion-tolerant gravel patches, and most of the work is done using hand tools, reconditioning present substrate by a method called Hartijoki (Stridsman 1995) or through the addition of external sediment brought to the sites during winter. A restored spawning bed has a $30-\mathrm{cm}$ deep layer of gravel and cobble, with a diameter of $2-10 \mathrm{~cm}$. The size of the spawning bed varies, with a minimum size of $4 \mathrm{~m}^{2}$. The spawning area restoration, resulting in 328 spawning beds in the demonstration sites, was completed during August-September of 2010 and 2011. The demonstration restoration resulted in a total of 4.8 ha of restored stream area, including areas that were previously dry, given channelization and closures of side channels.

\section{Analysis and monitoring}

To evaluate the hydraulic effects of channel restoration, preand postrestoration studies were performed in July-August 2010 and in July-September 2011, respectively. In both years, sampling was done at both low and medium flow conditions in the 10 demonstration and the 10 best-practice (reference) sites. Measurements during high flow conditions were not taken for safety reasons. Also, form roughness will not have as large of an effect on flows during high flows because of higher water depth to grain size ratio, so measurements during low flows were more important. Each stream with a demonstration site has a reference site upstream or, in a few cases, in a nearby stream within the same catchment. It would have been preferable to also include unmodified, pristine stream reaches in this study. However, as stressed by Helfield et al. (2007), streams that were used for timber floating generally do not have unimpacted reaches and if they do, these reaches were typically bypassed by the log drivers because they were too narrow or steep and, therefore, are not comparable to impacted reaches.

To obtain velocity and channel geometry measurements to make pre- and postrestoration comparisons, 10 cross sections were set up at each reach at even intervals. At each cross section, mean velocity was measured at five points, for a total of 50 velocity measurements per reach. Velocity measurements were taken at 0.6 of the depth below the water surface to obtain the average velocity for a given vertical profile. If a boulder was exposed above the water surface at a velocity-measuring point, the measurement was taken at the nearest possible location next to the original transect. The wetted channel width was also measured at each cross section. Discharge was calculated from measurements at one cross section per stream above a relatively homogeneous and narrow bottom. For this calculation, we measured flow velocity and depth at 8-11 points along the cross section. The product of the cross-sectional area $\left(\mathrm{m}^{2}\right)$ and the average current velocity $(\mathrm{m} / \mathrm{s})$ provides the discharge $\left(\mathrm{m}^{3} / \mathrm{s}\right)$. We were unable to obtain measurements at identical flow conditions in all streams before and after restoration. When field work was done before restoration, mean discharge values for all streams were 0.65 and $1.63 \mathrm{~m}^{3} / \mathrm{s}$ for low and medium flows, respectively. The corresponding values for the postrestoration field work were 0.66 and $2.03 \mathrm{~m}^{3} / \mathrm{s}$. Given the differing medium flow values, we analyzed data both individually for each flow level and for combined flows to attempt to control for differences in medium flow magnitudes.

To determine flow variability, the coefficient of variation (CV) of the velocity measurements was calculated for each reach for each measurement period. Pairwise $t$-test comparisons of velocity $\mathrm{CV}$ were made for reaches for the two time periods, 
Table 2. Pairwise comparisons of coefficient of variation $(\mathrm{CV})$ for velocity within a reach per measurement period for each flow period.

\begin{tabular}{|c|c|c|c|c|c|c|c|c|c|c|c|c|}
\hline & \multicolumn{6}{|c|}{ Reference and demonstration reaches compared } & \multicolumn{6}{|c|}{ Before and after restoration compared } \\
\hline & \multicolumn{2}{|c|}{ Low flows } & \multicolumn{2}{|c|}{ Medium flows } & \multicolumn{2}{|c|}{ All flows } & \multicolumn{2}{|c|}{ Low flows } & \multicolumn{2}{|c|}{ Medium flows } & \multicolumn{2}{|c|}{ All flows } \\
\hline & before & after & before & after & before & after & $\begin{array}{l}\text { best } \\
\text { practice }\end{array}$ & $\begin{array}{l}\text { demon- } \\
\text { stration }\end{array}$ & $\begin{array}{l}\text { best } \\
\text { practice }\end{array}$ & $\begin{array}{l}\text { demon- } \\
\text { stration }\end{array}$ & $\begin{array}{l}\text { best } \\
\text { practice }\end{array}$ & $\begin{array}{l}\text { demon- } \\
\text { stration } \\
\end{array}$ \\
\hline Mean difference & -0.14 & 0.04 & -0.04 & 0.04 & -0.09 & 0.04 & 0.07 & 0.24 & -0.02 & 0.12 & 0.03 & 0.17 \\
\hline$t$-statistic & -1.22 & 0.50 & -0.71 & 0.53 & -1.44 & 0.77 & 0.97 & 2.49 & -0.31 & 1.67 & 0.60 & 3.05 \\
\hline$p$-value (one-sided) & 0.18 & 0.34 & 0.29 & 0.33 & 0.14 & 0.29 & 0.24 & $\underline{0.03}$ & 0.36 & $\underline{0.09}$ & 0.33 & $\underline{0.01}$ \\
\hline
\end{tabular}

Note: Significant differences $(\alpha=0.1)$ are underlined.

before and after restoration on demonstration reaches, testing the null hypothesis that the difference in velocity CV was zero between the two time periods. Pairwise comparisons were also made for reference versus demonstration reaches on the same stream before and after restoration to determine whether the demonstration restoration showed significantly different velocity variation than in reference reaches. Finally, $t$-tests were used to evaluate the differences in current velocity and channel width in the demonstration and best practice sites before and after restoration.

\section{RESULTS}

Qualitatively, structural heterogeneity increased by applying demonstration methods to reaches previously restored by bestpractice methods (Fig. 3 and 4). We can also show this quantitatively with significant effects $(\alpha=0.05)$ of restoration on both current velocity and channel width in the demonstration sites, combining sites and flow levels. The average current velocity for all reaches decreased by $24 \%$ and channel width increased by $13 \%$ after restoration of the demonstration sites (Table 1). The reference sites, which

Fig. 3. Section of the Olsbäcken stream after best-practice restoration, where sediment that had lined the channel margins during timber floating has been placed back into the channel. (Photograph: Daniel Jonsson)

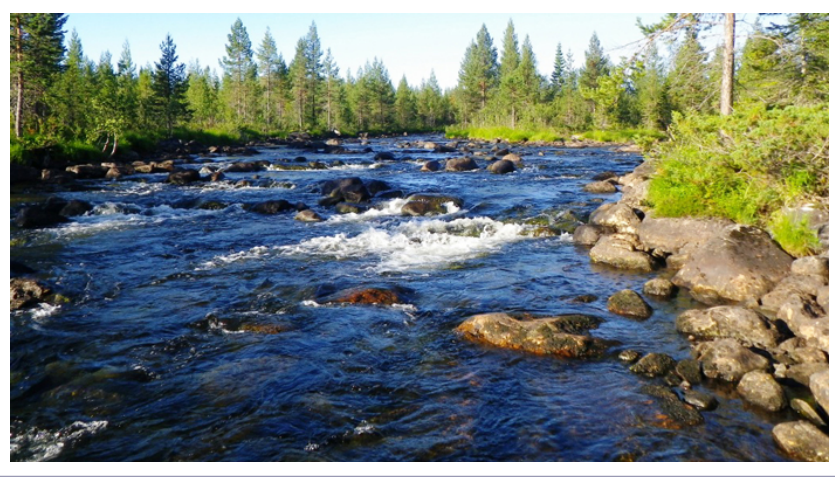

were restored before this study began, did not show any statistically significant changes for these variables between the two time periods ( $\alpha=0.05$, Table 1$)$, suggesting that the observed difference for the demonstration sites represented a real change. Velocity $\mathrm{CV}$ showed a significant increase between before and after restoration at demonstration sites using pairwise comparisons for low flows $(\alpha=0.05)$, medium flows $(\alpha=0.10)$, and combined flows $(\alpha=0.01)$ (Table 2$)$. No significant differences were observed between the two measurement years at reference sites. The lowest increase in velocity $\mathrm{CV}$ at the demonstration sites was observed for medium flows and can be explained by the increase in relative submergence (ratio of hydraulic radius to $84^{\text {th }}$ percentile grain size), which decreases the roughness. Pairwise comparisons of velocity $\mathrm{CV}$ between reference and demonstration sites on the same stream did not show any significant differences before restoration of demonstration sites, which is to be expected. However, there was also no significant difference in velocity $\mathrm{CV}$ values between the reference and demonstration reaches on the same stream after restoration of

Fig. 4. Section of the Olsbäcken stream where additional restoration, using demonstration methods, has been applied to the same reach as depicted in Fig. 3, meaning that large boulders and large wood from upland areas have been added to the channel. (Photograph: Daniel Jonsson)

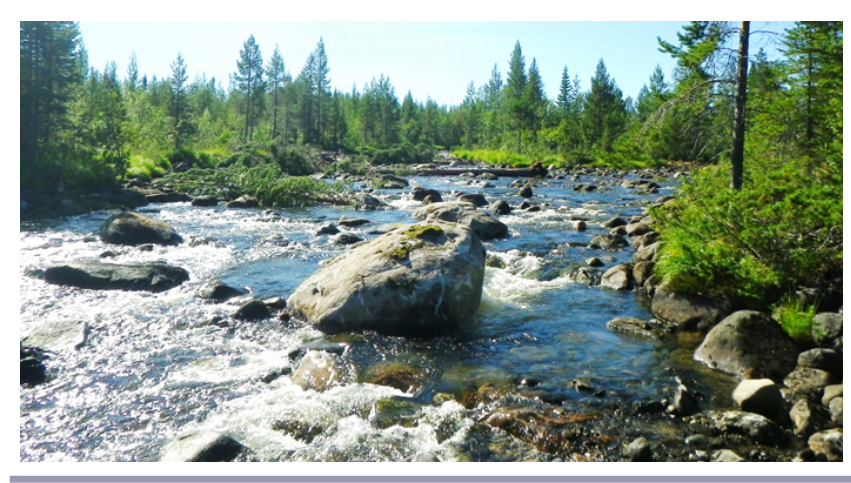


demonstration sites. Although the mean difference in velocity $\mathrm{CV}$ was positive for all flow levels tested separately and combined, differences before restoration were negative. Therefore, the lack of significance between reference and restoration reaches after restoration could be due to lower prerestoration velocity $\mathrm{CV}$ values in the demonstration reaches.

\section{DISCUSSION}

The Vindel River LIFE project is a good example of a largescale river restoration effort that does not simply use standard, best-practice measures in rehabilitating the instream environment and its surroundings. The project also challenges these measures by testing and monitoring the effects of new, innovative restoration methods. In general, stream restoration has produced somewhat ambiguous results. For example, in some stream reaches, the current best-practice methods have been shown to enhance biodiversity (Helfield et al. 2007), whereas in others there has been no effect (Lepori et al. 2005). It may be that best-practice restoration does not produce the best possible result because the original channel material available to be placed back in the channels was broken up (boulders) or eliminated (large wood) as a result of channelization (Nilsson et al. 2005a). By adding large structures from adjacent upland areas, more heterogeneous morphologic and hydraulic channel conditions are created, hopefully leading to a clearer biotic response. Still, habitat heterogeneity is not an automatic path to success. For example, many studies (Palmer at al. 2010) have failed to show any effect of restoration of instream heterogeneity on invertebrate diversity, probably because stressors other than low habitat heterogeneity limit biota.

One might argue that it is difficult to know the optimal amount of large structures in individual stream reaches (Dahlström and Nilsson 2004). However, the quantity of blasted boulders in the respective area-usually moved to the edges of the channel-along with the quantity of big boulders in adjacent uplands, provides a reliable indication. Rare examples of stream reaches that were not channelized show that boulder richness could be extremely high (Fig. 5), indicating that stream reaches have not been restored beyond natural ranges. However, these unchannelized reaches have higher gradients and, thus, we expect them to contain slightly larger boulders (Polvi, personal observation). For the current project, demonstration sites were only located close to rapids with boulder-rich surroundings. In fact, these boulders are erratics deposited during the melting of the last inland ice and not embedded in fine sediment, implying that they can be removed without leaving holes in the ground, thus not creating a large ecological disturbance.

According to flow resistance equations such as Manning's equation (e.g., Knighton 1998), the larger structures placed in stream channels will increase roughness, thus reducing flow velocity, which can attenuate downstream flooding. This, in turn, is predicted to retain drifting matter (Nilsson et al. 2005a, Rosenfeld et al. 2011), offer fish shelter from predators and fast flows, as well as provide hydraulically suitable feeding locations (Palm et al. 2007). In small streams, large wood has been shown to be an important channel-forming agent, affecting channel morphology by trapping sediment, creating steps and pools, and triggering avulsions (Faustini and Jones 2003, Dahlström and Nilsson 2004, Gurnell et al. 2005). Our results suggest that the demonstration actions have provided conditions for such changes by increasing the water-retention capacity and the hydraulic heterogeneity of restored stream reaches. The observed decrease in the heterogeneity of the channel width after restoration is probably a function of greater channel-floodplain connectivity; i.e., the channel is no longer locally blocked from its floodplain. Although more detailed measurements of channel geometry could be taken to quantify heterogeneity more precisely, we focused on wetted width and velocity variation, to permit the time to measure 20 reaches during similar flow levels both before and after restoration. Detailed measurements of geomorphic complexity could elucidate further differences in abiotic effects of demonstration restoration.

Fig. 5.Section of the Baksjöbäcken stream in southern Lapland, in northern Sweden, showing an example of a stream containing very high volumes of boulders. Note: Timber floating across such sections was done using flumes beside the stream (Smeds 2008). (Photograph: Roger Vallin)

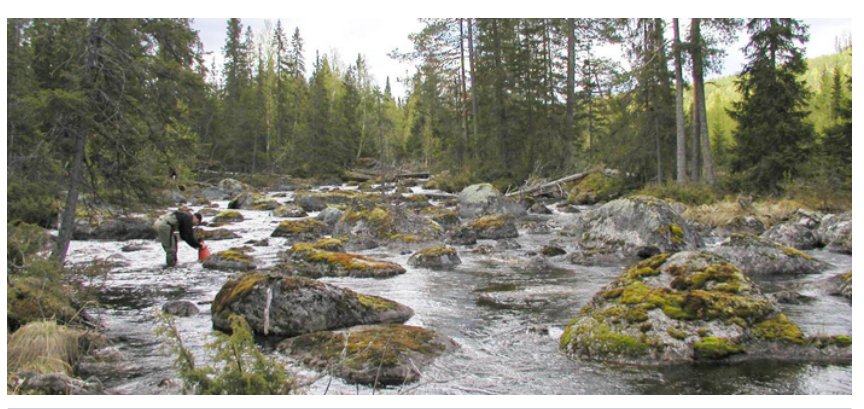

Not only are the instream restoration methods important in conducting experimental restoration, but the methods of obtaining stakeholder support are also vital for successful restoration. In our experiences with restoration, we met some resistance from local landowners who questioned the practice of placing boulders back into the channels; they may be even more concerned about adding yet more material. A common misconception is that the water will "disappear" and that, for example, fishing will become difficult or even impossible. Large pieces of wood in channels may not improve this misconception. Those people should be relieved by our present results, which show that flow velocity decreases and that channel width and volume increase after restoration. As we 
discussed earlier, meetings with all stakeholders prior to restoration efforts provided a forum where everyone had the opportunity to voice concerns and be informed. Preliminary, qualitative results of increased fish activity have increased landowner support of the restoration project.

We conclude that the demonstration restoration has increased the hydraulic heterogeneity of the streams, thus paving the way for organisms to respond. However, biotic effects of restoration remain to be studied. Biotic responses may appear at both local (reach) and regional (catchment) scales. Overall, the project relies heavily on the "field of dreams" hypothesis, stating that if suitable abiotic conditions are created, organisms will invade by themselves (Palmer et al. 1997). This assumes that organisms are available, if not locally, at least regionally, and that they are able to move to the particular site. For example, tributaries provide important nursery habitats for many fish species and, hence, restoration of such areas is important not only for local populations but also for fish that migrate from the main channel (Crisp 2000, Bagliniere and Maisse 2002). The opening and reconnection of side channels, which happens in most tributaries as a result of boulder placement, will have a similar effect on fish, although at a somewhat smaller scale. However, the effects on local species richness are more difficult to predict (Lepori et al. 2005, Helfield et al. 2012). It is likely that both a scale effect and a time effect are involved here. As suggested by Jähnig et al. (2010), ecological improvements in the demonstration sites should not be ascribed only to this particular type of restoration, but perhaps as a cumulative effect of restoration at the catchment scale, including numerous best-practice reaches. In fact, the majority of the rapids in the catchment are being restored using best-practice methods. It could also be the opposite, namely that demonstration sites have the capacity to enhance biotic responses but that the number of such sites needs to be multiplied for effects to be measurable. The reason that Helfield et al. (2007) observed an increase in plant diversity whereas Lepori et al. (2005) failed to find any effects on macroinvertebrate or fish diversity after restoration could depend on an as-yet incomplete response of the ecological community. For example, although riparian plant species numbers had increased, the development of mature riparian forests and rich stands of aquatic macrophytes and periphyton will probably require a much longer time until they reach levels that result in a measurable response in aquatic macroinvertebrates or fish (cf. Hansen and Hayes 2012).

Finally, although it is still too early to evaluate the overall results of the demonstration restoration, available data and experiences suggest that this type of restoration represents an improvement over the current best practices in terms of methods, abiotic effects, and stakeholder support. One reason for stream restoration in northern Europe is the rehabilitation of brown trout populations, which are popular game fish. Reconstruction of lost spawning beds and retention of added spawning bed substrate is key for success in this matter (Rosenfeld et al. 2011, Luhta et al. 2012) and these goals are more likely to be reached in slow-flowing, boulder-rich stream reaches like the demonstration sites. Another reason for stream restoration is increasing water retention during heavy rains and flood-erosion events, predicted to become more frequent as a result of climate change (Nilsson et al. 2013). In this case, demonstration sites are also likely to be the most efficient. A weakness with the demonstration restoration in the Vindel River LIFE project is that the demonstration sites are few and scattered. It may be that the majority of rapids that were impacted by channelization during the timber-floating period would need to be restored using demonstration methods to achieve significant effects at the catchment scale. Future work will judge whether demonstration restoration should become the new best practice, but the results we have so far do point in favor of such a change.

Responses to this article can be read online at: http://www.ecologyandsociety.org/issues/responses. php/5609

\section{Acknowledgments:}

The work presented in the paper was carried out as part of the Vindel River LIFE project (LIFE08 NAT/S/000266), funded by the European Commission, the Swedish Environmental Protection Agency, the County Administration Board of Västerbotten, the municipalities of Arjeplog, Sorsele, Lycksele, Vindeln, Vännäs and Umeå, Umeå University, the Vindel River Fishery Advisory Board, and the Swedish University of Agricultural Sciences. The manuscript benefitted from comments by Gunnel Grelsson and three anonymous reviewers. We thank Petter Esberg, Filip Liljeståhl, Lovisa Lind, Sofi Lundbäck, and Anneli Sandström for assistance in the field.

\section{LITERATURE CITED}

Arthington, A. H., R. J. Naiman, M. E. McClain, and C. Nilsson. 2010. Preserving the biodiversity and ecological services of rivers: new challenges and research opportunities. Freshwater Biology 55:1-16. http://dx.doi.org/10.1111/ j.1365-2427.2009.02340.x

Bagliniere, J. L., and G. Maisse. 2002. The biology of brown trout, Salmo trutta L., in the Scorff River, Brittany: a synthesis of studies from 1972 to 1997. Productions Animales 15:319_ 331.

Bednarek, A. T. 2001. Undamming rivers: a review of the ecological impacts of dam removal. Environmental Management 27:803-814. http://dx.doi.org/10.1007/s002670010189 
Bernhardt, E. S., M. A. Palmer, J. D. Allan, G. Alexander, K. Barnas, S. Brooks, J. Carr, S. Clayton, C. Dahm, J. FollstadShah, D. Galat, S. Gloss, P. Goodwin, D. Hart, B. Hassett, R. Jenkinson, S. Katz, G. M. Kondolf, P. S. Lake, R. Lave, J. L. Meyer, T. K. O’Donnell, L. Pagano, B. Powell, and E. Sudduth. 2005. Synthesizing U.S. river restoration efforts. Science 308:636-637. http://dx.doi.org/10.1126/science.1109769

Brookes, A. 2011. Review of EU policy drivers for river restoration. Environment Agency, Rotherham, UK.

Crisp, D. T. 2000. Trout and salmon: ecology, conservation and rehabilitation. Fishing News Books, Oxford, UK. http:// dx.doi.org/10.1002/9780470999776

Dahlström, N., and C. Nilsson. 2004. Influence of woody debris on channel structure in old growth and managed forest streams in central Sweden. Environmental Management 33:376-384. http://dx.doi.org/10.1007/s00267-003-3042-2

Dynesius, M., and C. Nilsson. 1994. Fragmentation and flow regulation of river systems in the northern third of the world. Science 266:753-762. http://dx.doi.org/10.1126/science.266.5186.753

Faustini, J. M., and J. A. Jones. 2003. Influence of large woody debris on channel morphology and dynamics in steep, boulderrich mountain streams, Western Cascades, Oregon. Geomorphology 51:187-205. $\quad$ http://dx.doi.org/10.1016/ S0169-555X(02)00336-7

Gurnell, A., K. Tockner, P. Edwards, and G. Petts. 2005. Effects of deposited wood on biocomplexity of river corridors. Frontiers in Ecology and the Environment 3:377-382. http:// dx.doi.org/10.1890/1540-9295(2005)003[0377:EODWOB]2.0. $\mathrm{CO} ; 2$

Hansen, J. F., and D. B. Hayes. 2012. Long-term implications of dam removal for macroinvertebrate communities in Michigan and Wisconsin rivers, United States. River Research and Applications 28:1540-1550. http://dx.doi.org/10.1002/ rra.1540

Helfield, J. M., S. J. Capon, C. Nilsson, R. Jansson, and D. Palm. 2007. Restoration of rivers used for timber floating: effects on riparian plant diversity. Ecological Applications 17:840-851. http://dx.doi.org/10.1890/06-0343

Helfield, J. M., J. Engström, J. T. Michel, C. Nilsson, and R. Jansson. 2012. Effects of river restoration on riparian biodiversity in secondary channels of the Pite River, Sweden. Environmental Management 49:130-141. http://dx.doi. org/10.1007/s00267-011-9773-6

Hilderbrand, R. H., A. C. Watts, and A. M. Randle. 2005. The myths of restoration ecology. Ecology and Society 10(1): 19. [online] URL: http://www.ecologyandsociety.org/vol10/iss1/ art19/
Jähnig, S. C., K. Brabec, A. Buffagni, S. Erba, A. W. Lorenz, T. Ofenböck, P. F. M. Verdonschot, and D. Hering. 2010. A comparative analysis of restoration measures and their effects on hydromorphology and benthic invertebrates in 26 central and southern European rivers. Journal of Applied Ecology 47:671-680. http://dx.doi.org/10.1111/j.1365-2664.2010.01807. $\mathrm{x}$

Jähnig, S. C., A. W. Lorenz, D. Hering, C. Antons, A. Sundermann, E. Jedicke, and P. Haase. 2011. River restoration success: a question of perception. Ecological Applications 21:2007-2015. http://dx.doi.org/10.1890/10-0618.1

Knighton, D. 1998. Fluvial forms and processes: a new perspective. Arnold, London, UK.

Kondolf, G. M., S. D. Anderson, R. Storesund, M. Tompkins, and P. Atwood. 2011. Post-project appraisals of river restoration in advanced university instruction. Restoration Ecology 19:696-700. http://dx.doi.org/10.1111/

j.1526-100X.2011.00803.x

Lejon, A. G. C., B. M. Renöfält, and C. Nilsson. 2009. Conflicts associated with dam removal in Sweden. Ecology and Society 14(2): 4. [online] URL: http://www. ecologyandsociety.org/vol14/iss $2 /$ art4

Lepori, F., D. Palm, E. Brännäs, and B. Malmqvist. 2005. Does restoration of structural heterogeneity in streams enhance fish and macroinvertebrate diversity? Ecological Applications 15:2060-2071. http://dx.doi.org/10.1890/04-1372

Luhta, P.-L., A. Huusko, and P. Louhi. 2012. Re-building brown trout populations in dredged boreal forest streams: instream restoration combined with stocking of young trout. Freshwater Biology 57:1966-1977. http://dx.doi.org/10.1111/ j.1365-2427.2012.02850.x

Maddock, I. 1999. The importance of physical habitat assessment for evaluating river health. Freshwater Biology 41:373-391. http://dx.doi.org/10.1046/j.1365-2427.1999.00437. $\underline{\mathrm{X}}$

Malmqvist, B., and S. Rundle. 2002. Threats to the running water ecosystems of the world. Environmental Conservation 29:134-153. http://dx.doi.org/10.1017/S0376892902000097

Nardini, A., and S. Pavan. 2012. River restoration: not only for the sake of nature but also for saving money while addressing flood risk: a decision-making framework applied to the Chiese River (Po basin, Italy). Journal of Flood Risk Management 5:111-133. http://dx.doi.org/10.1111/ j.1753-318X.2011.01132.X

Nilsson, C., editor. 2007. Återställning av älvar som använts för flottning: en vägledning för restaurering. Rapport 5649, Naturvårdsverket, Stockholm, Sweden. http://www.naturvardsverket. se/Documents/publikationer/620-5649-2.pdf 
Nilsson, C., A. Ekblad, M. Dynesius, S. Backe, M. Gardfjell, B. Carlberg, S. Hellqvist, and R. Jansson. 1994. A comparison of species richness and traits of riparian plants between a main river channel and its tributaries. Journal of Ecology 82:281295. http://dx.doi.org/10.2307/2261296

Nilsson, C., F. Lepori, B. Malmqvist, E. Törnlund, N., Hjerdt, J. M. Helfield, D. Palm, J. Östergren, R. Jansson, E. Brännäs, and H. Lundqvist. 2005a. Forecasting environmental responses to restoration of rivers used as log floatways: an interdisciplinary challenge. Ecosystems 8:779-800. http://dx. doi.org/10.1007/s10021-005-0030-9

Nilsson, C., C. A. Reidy, M. Dynesius, and C. Revenga. 2005 b. Fragmentation and flow regulation of the world's largest river systems. Science 308:405-408. http://dx.doi.org/10.1126/ science. 1107887

Nilsson, C., R. Jansson, B. Malmqvist, and R. J. Naiman. 2007. Restoring riverine landscapes: the challenge of identifying priorities, reference states, and techniques. Ecology and Society 12(1): 16. [online] URL: http://www.ecologyandsociety. org/vol12/iss1/art16/

Nilsson, C., R. Jansson, L. Kuglerová, L. Lind, and L. Ström. 2013. Boreal riparian zones under climate change. Ecosystems 16:401-410. http://dx.doi.org/10.1007/s10021-012-9622-3

Palm, D., E. Brännäs, F. Lepori, K. Nilsson, and S. Stridsman. 2007. The influence of spawning habitat restoration on the density of juvenile brown trout (Salmo trutta L.). Canadian Journal of Fisheries and Aquatic Sciences 64:509-515. http:// dx.doi.org/10.1139/f07-027

Palmer, M. A., R. F. Ambrose, and N. L. Poff. 1997. Ecological theory and community restoration ecology. Restoration Ecology 5:291-300. http://dx.doi.org/10.1046/

j.1526-100X.1997.00543.X

Palmer, M. A., H. L. Menninger, and E. Bernhardt. 2010. River restoration, habitat heterogeneity and biodiversity: a failure of theory or practice? Freshwater Biology 55:205-222. http://dx. doi.org/10.1111/j.1365-2427.2009.02372.x

Palmer, M. A., C. A. Reidy, C. Nilsson, M. Flörke, J. Alcamo, P. S. Lake, and N. Bond. 2008. Climate change and the world's river basins: anticipating management options. Frontiers in Ecology and the Environment 6:81-89. http://dx.doi. org/10.1890/060148

Rosenfeld, J., D. Hogan, D. Palm, H. Lundqvist, C. Nilsson, and T. J. Beechie. 2011. Contrasting landscape influences on sediment supply and stream restoration priorities in northern Fennoscandia (Sweden and Finland) and coastal British Columbia. Environmental Management 47:28-39. http://dx. doi.org/10.1007/s00267-010-9585-0

Smeds, R. 2008. Kulturhistorisk dokumentation av flottningslämningar i Baksjöbäcken och Hörnån, Västerbottens län. Västerbottens Museum, Umeå, Sweden. http://www. sparfran10000ar.se/assets/files/Pdf-rapporter/Asele/2008 Flott AseleochUmea.pdf

Swedish Meteorological and Hydrological Institute (SMHI). 1979. Streamflow records of Sweden. Liber Förlag, Stockholm, Sweden.

Stridsman, S. 1995. Fiskevårdsåtgärder $i$ Hartijoki, Kalixälvens vattensystem 1992-1994. Fiskeriverket, Luleå, Sweden.

Tharme, R. E. 2003. A global perspective on environmental flow assessment: emerging trends in the development and application of environmental flow methodologies for rivers. River Research and Applications 19:397-441. http://dx.doi. org/10.1002/rra.736

Törnlund, E., and L. Östlund. 2000. Flottning: vattendraget, arbetet, berättelserna. Skrifter om Skogs- och Lantbrukshistoria 14:1-203.

Törnlund, E., and L. Östlund. 2002. Floating timber in northern Sweden: the construction of floatways and transformation of rivers. Environment and History 8:85-106. http://dx.doi. org/10.3197/096734002129342611 